NR 19 (28)

BIBLIOTEKA

2015 PL ISSN 1506-3615

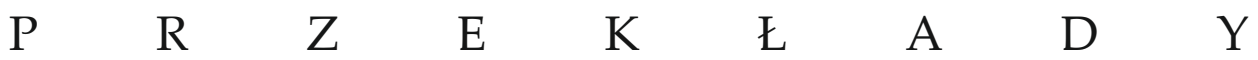

MARTIN FENNER

Hannover Medical School, Hannover, Germany and Public Library of Science, San Francisco, CA, USA; mfenner@plos.org

JENNIFER LIN

Public Library of Science, San Francisco, CA, USA; jlin@plos.org

\title{
ALM - nowatorskie metryki wskaźników wpływu w publikacjach naukowych ${ }^{1}$
}

\begin{abstract}
Streszczenie. Cytowania przytaczane w literaturze światowej, a ostatnio statystyki wykorzystania materiału naukowego dostarczające informacji na temat zainteresowania i oddźwięku, jakie zdobywają publikacje naukowe, nadal pozostają ważnymi wskaźnikami wpływu w ocenie publikacji. Ukazują one bowiem widoczny wkład danej pracy naukowej w rozwój nauki i badań. Public Library of Science (PLOS), platforma projektu typu non profit oferująca dostęp do czasopism naukowych na zasadzie licencji wolnej dokumentacji oraz wydawca publikacji typu open access, była jednym z pierwszych tego typu projektów, w którym wprowadzono możliwość analizy innowacyjnych metryk, tzw. article-level metrics (ALM), tj. badania wpływu publikacji naukowych na poziomie artykułu, a nie czasopisma, z uwzględnieniem zmian, jakie zaszły w komunikacji naukowej wraz z rozwojem sieci. Badania uzupełniane są danymi kontekstowymi świadczącymi o zakresie społecznej uwagi poświęcanej danej pracy naukowej, uzyskiwanymi w czasie rzeczywistym z naukowych portali społecznościowych lub z alternatywnych metryk, takich jak blogi naukowe, zakładki, media społecznościowe.
\end{abstract}

SŁowA KLuCzowe: metryki na poziomie artykułu, wskaźniki wpływu dla publikacji naukowych, alternatywne metryki - altmetryka.

\section{Wstęp}

W celu zwiększenia nakładów przeznaczonych na gromadzenie literatury $\mathrm{w}$ bibliotekach bibliotekarze przez wiele lat wykorzystywali jako

1 This work is licensed under a Creative Commons Attribution 3.0 Unported license Igitur publishing (http://liber.library.uu.nl/) URN:NBN:NL:UI:10-1-116067; „Liber Quarterly” 2014, t. 23 z. 4. 
miernik wartości prac statystki użytkowania artykułów z publikacji naukowych. W przeszłości jednak sama czynność zabrania z półki w czytelni jakiegoś numeru czasopisma nie pozostawiała żadnego wymiernego śladu i nie mogła być w żaden sposób odnotowana. W tej sytuacji bibliotekarzom pozostawało jedynie opieranie się na statystycznych raportach na temat zamówień na poszczególne tytuły, składanych przez użytkowników bibliotek. Takie sprawozdania dostarczały dane pozwalające na podejmowanie istotnych decyzji dotyczących zestawów publikowanej literatury naukowej do przyszłego udostępniania społeczności akademickiej. Informacja pozyskiwana w ten sposób nie dawała szerszego wglądu w zakres wykorzystania czasopism.

Ogół społeczności naukowej w zasadzie stosował podobny model oceny w komunikacji naukowej, i to wobec wszelkich ewentualnych potrzeb. W ekosystemie akademickim i naukowym przeważającym paradygmatem pomiaru wagi badań naukowych jest paradygmat oparty na użyciu oceny tytułu czasopisma jako całości. Nadużywanie wskaźnika Journal Impact Factor w systemie wartościowania publikacji skłoniło jednak grupę wybitnych badaczy zajmujących się bibliometria, naukowców, wydawców, a także decydentów do opracowania nowych innowacyjnych technik pozwalających na dokonywanie oceny wartości publikacji naukowych również za pomocą komplementarnych alternatywnych metod, takich jak efektywne wykorzystanie wskaźnika article-level metrics (ALM) w ewaluacji zainteresowania danym materiałem.

W dzisiejszym środowisku cyfrowym naukowcy mogą korzystać z szerokiego spektrum sposobów dostępu do publikacji innych naukowców, zarządzania nimi, współdzielenia się, ich komentowania, a wreszcie cytowania. Już samo środowisko cyfrowe umożliwia jednocześnie gromadzenie i analizę zapisów takiej działalności. W roku 2009 Public Library of Science (PLOS) jako pierwszy wydawca ${ }^{2}$ przystąpił do aktywnej prezentacji mierników wpływu na poziomie artykułu, umożliwiając wgląd $\mathrm{w}$ bardziej skoncentrowaną i indywidualną informację na temat uznanej wartości danego materiału naukowego oraz sposobu docierania do niego. Prezentując metryki na poziomie artykułu (ALM) ${ }^{3}$, PLOS zaproponował dostęp do przejrzystej i wszechstronnej informacji o wykorzystaniu i rzeczywistym dostępie do publikowanych artykułów na stronach

2 C. Neylon, S. Wu, Article-level metrics and the evolution of scientific impact, "PLOS Biology" 2009, t. 7 (11), e1000242, http://www.plosbiology.org/article/ info\%3Adoi\%2 F10.1371\%2Fjournal.pbio.1000242 [dostęp: 11.05.2013].

3 PLOS Article-level metrics (ALMs): measuring the impact of research, http://articlelevel-metrics.plos.org [dostęp: 15.04.2013]. 
WWW w taki sposób, by każda zainteresowana grupa czytelnicza sama mogła dokonać ewaluacji ich wartości na podstawie kluczowych danych decydujących o zróżnicowanych potrzebach odbiorców. ALM oferuje zatem bezpośrednie opinie, uzyskane z pierwszej ręki, o rozpowszechnianiu i dostępie do artykułów naukowych za pomocą coraz bardziej rozszerzanego asortymentu różnego rodzaju metryk, od tradycyjnych, opierających się na pomiarze wykorzystania materiału, do całej mozaiki danych dostarczanych przez media społecznościowe. Taki wielowymiarowy zestaw wskaźników pozwala na śledzenie całego łańcucha wiedzy, prestiżu i oddziaływania artykułu już od momentu jego publikacji, potem jego wpływu na środowisko naukowe w mijającym czasie. Zestaw obecnie istniejących metryk podsumowano na rysunku 1.

Dzisiaj, gdy prawie wszystkie artykuły są dostępne online, zaistniała możliwość dokonania wiarygodnego pomiaru czytelnictwa i ich oceny przez użytkowników. Uzyskując wgląd w to, jak naukowcy zaangażowani są w swoje badania, możemy spróbować określić typ poszczególnych odbiorców i cele rozpowszechniania tekstów. Zróżnicowane typy usług świadczonych w sieci, takie jak dodawanie zakładek, serwisy zarządzania bibliografia portale społecznościowe, rekomendacje, komentarze zamieszczone na stronach wydawców czy wreszcie repozytoria danych, pozwalają poznać zakres społecznej uwagi poświęcanej danej pracy naukowej.

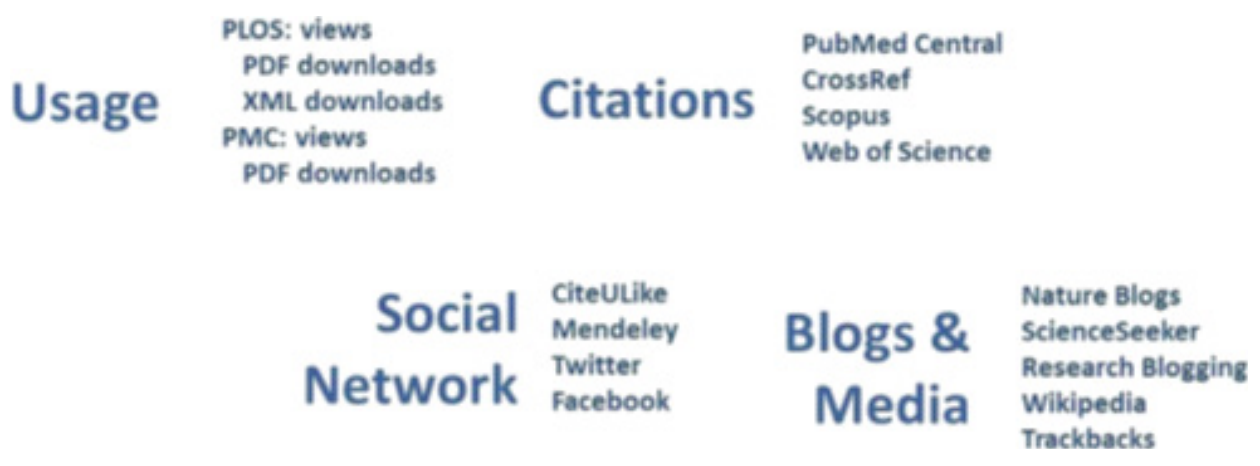

Rysunek 1. Metryki ALM zbierane i udostępniane przez PLOS

Nowe media i narzędzia umożliwiające wszystkim użytkownikom internetu partycypację w zadaniach, które kiedyś były zarezerwowane dla wąskiej grupy w procesie działalności popublikacyjnej (crowdsourcing), wspomagają naukowców w ocenie i wartościowaniu artykułów naukowych na podstawie ich wartości merytorycznej, a także siły wynikającej z zajmowanej pozycji w środowisku (wzmocnionej dodatkowo procesem 
anonimowej i niezależnej recenzji naukowej). Poszerzają zatem zasięg istniejących środków oceny wpływu związanych z danym tytułem czasopisma naukowego lub wydawcy i stwarzają warunki do odkrywania i filtrowania artykułów.

Co więcej, dane pochodzące z ALM umożliwiają transparentne śledzenie odwzorowania i analizy osobistych relacji pomiędzy naukowcami, dostarczają $\mathrm{w}$ ten sposób narzędzi pomocnych $\mathrm{w}$ ich wymiernej ocenie na skalę dotąd nieosiągalną. Pozwalają zatem badaczom na rozpoznanie, które $\mathrm{z}$ naukowych artykułów i tytułów naprawdę są centralne $\mathrm{w}$ indywidualnym przepływie informacyjnym. Dane dostarczane przez metryki ALM zapewniają uzyskanie istotnych informacji, które zawierają w sobie potencjał do dalszego działania w wielu dziedzinach nauki w zakresie:

\section{Oceny naukowej}

- Ewaluacja merytorycznej wartości rzeczywistych indywidualnych badań, a nie wynikająca z oceny tytułu czasopisma naukowego publikującego artykuł.

- Dogłębna, oparta na rzetelnej wiedzy perspektywa dająca podstawy do podejmowania adekwatnych i bezstronnych decyzji związanych $\mathrm{z}$ danymi badaniami (np. finansowanie, promocja, naukowa percepcja), wspomagana przejrzystą i wszechstronną analizą poziomu wpływu.

Wyszukiwania treści naukowych

- Spersonalizowane poszukiwania literatury (nawigacja, filtrowanie i sortowanie) na zogniskowane odkrycia badawcze.

- Wzmocnienie jakościowe odkryć badawczych przez cenne rekomendacje środowiskowe oparte na wskaźnikach zbiorowej inteligencji.

\section{Monitorowania i śledzenia prac naukowych}

- Wydajny i zoptymalizowany sposób utrzymania wysokiego poziomu świadomości i wiedzy o ostatnich publikacjach w konkretnej dziedzinie nauki i generalnie $\mathrm{w}$ nauce.

- Ocena i ekspertyza najnowszych tendencji na podstawie najbardziej aktualnych metryk przedstawiających pomiar oddziaływania danego artykułu.

\section{Procesu naukowego}

- Uaktualniony obraz postępu badań naukowych, który jednocześnie z łatwością można współdzielić z innymi (np. z administratorami instytucji, instytucjami zapewniającymi finansowanie badań).

- Ułatwione przygotowywanie projektów oraz ich późniejsza implementacja z wykorzystaniem doskonalszego i precyzyjnego wglądu w rozwój badań na danym polu naukowym. 
- Przemyślany dobór współpracowników na podstawie wskaźników wpływu ich indywidualnych prac i poziomu relewancji tychże do prac zarządzających projektami.

\section{Article-level metrics w szczegółach}

Najistotniejszą wartościa, jaką oferuje ALM, jest możliwość zwiększenia różnorodności danych, które zamierzamy zebrać. Takie podejście odzwierciedla rosnące zrozumienie potrzeby pomiaru wpływu wykraczającego poza krąg społeczności akademickiej. Jednocześnie tradycyjne sposoby pomiaru wpływu nadal pozostają ważne, a dane uzyskiwane za pomocą ALM mają jedynie charakter danych komplementarnych. Niezmiennie cytowanie piśmiennictwa pozostaje wysokiej jakości metryką wpływu na innych badaczy. Oprócz cytowań są jednak jeszcze inne, nowe mierniki, które także dostarczają wiedzy o formach wykorzystania, a które jeszcze do niedawna w dużej części nie były eksplorowane. Dziś są już do naszej dyspozycji i umożliwiają regularną aktualizację naukowego kontekstu danego artykułu, zanim jego cytowania zaczną się pojawiać w literaturze (co zresztą często trwa nawet lata po dacie publikacji artykułu). Zróżnicowany zestaw wskaźników wpływu umożliwia zastosowanie wielu sposobów oceny i nawigacji wśród dostępnych danych badawczych najbardziej związanych z daną dziedziną nauki, w tym: wykorzystanie materiału naukowego, cytowanie, zakładki i komentarze na blogach naukowych i portalach społecznościowych, a także działalność współdzielenia i rozpowszechniania, informacje zamieszczane $\mathrm{w}$ mediach czy wreszcie wywołana dyskusja i towarzysząca temu ocena wartości oraz wskaźnik popularności.

Pakiet ALM PLOS zawiera cytowania z różnych źródeł: CrossRef, Web of Science, Scopus czy PubMed Central. Cytowania zamieszczane w Google Scholar nie są uwzględnione, ponieważ nie da się ich automatycznie pozyskać przez API.

Ponad 90\% artykułów starszych niż dwa lata doczekuje się przynajmniej jednorazowego cytowania we wspomnianych serwisach. Procentowy wynik dla wszystkich artykułów to $60 \%$ (rysunek 2).

Wartości dotyczące wykorzystania dostarczane są oddzielnie dla odsłon konkretnych stron w HTML-u i dla pobrań plików w formacie PDF, a także dla dwóch odrębnych źródeł, tzn. strony domowej PLOS i repozytorium PubMed Central. Na stronie PLOS nie ma strony docelowej zawierającej abstrakty. Największe wykorzystanie ma strona domowa PLOS: 83,6\% wszystkich odsłon stron HTML i 68,6\% wszystkich pobrań 
plików PDF (dane zbierane od kwietnia 2013 roku). Dane dotyczące wykorzystania materiałów pochodzących z repozytoriów instytucjonalnych nie są aktualnie uwzględniane w metrykach ALM. PLOS i PubMed Central nie zbierają też danych na temat geograficznej lokalizacji związanej $\mathrm{z}$ wykorzystaniem.

Altmetryka śledzi wpływ danego artykułu naukowego i jego odbiór na stronach społecznościowych. Metryka może zawierać użyteczne informacje na temat danej pracy, jeśli spełnia następujące warunki: a) artykuł jest dostępny przez interfejs aplikacji z wykorzystaniem identyfikatora artykułu DOI lub innego stałego identyfikatora, b) jest w stanie śledzić pokaźną część wszystkich artykułów, c) pozwala na pomiar wywołanego zainteresowania $\mathrm{w}$ środowisku naukowym. Z kolei głównym ograniczeniem jest pierwszy warunek - i to właśnie stanowi największe wyzwanie w procesie śledzenia zasięgu oddziaływania artykułu naukowego. Zakres włączenia różnych źródeł przez dane dostarczane przez alternatywne metryki jest różny i obejmuje nawet przedział od mniej niż 1\% do niemal $70 \%$ (rysunek 2).

Popularność źródeł składających się na alternatywne metryki zmienia się wraz z upływem czasu, podobnie zresztą jak przekształcają się wzorce komunikacji międzynaukowej. Podczas gdy wpisy na blogach naukowych (ScienceSeeker i Research Blogging) oraz komentarze wyrażane na stronie internetowej PLOS zmniejszyły się w proporcji do liczby opublikowanych artykułów, Twitter stał się bardziej popularny i to właśnie tam

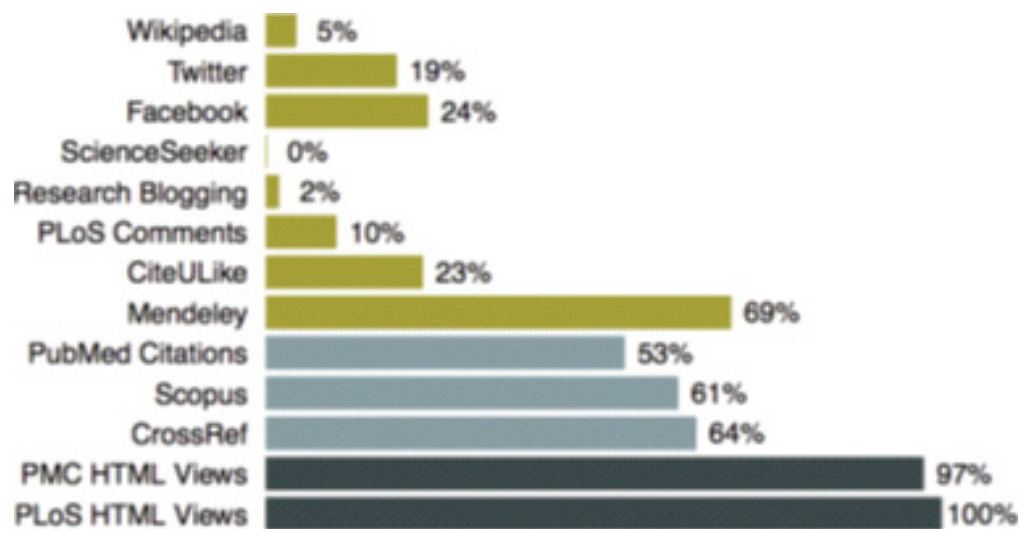

Rysunek 2. Proporcja artykułów według źródła. Metryki dla 77385 artykułów z PLOS. Dane zebrano w kwietniu 2013 roku. Poszczególne kolory wskazują na kategorię ALM (kolor żółty - altmetryka, kolor jasnoniebieski - cytowania, kolor ciemnoniebieski - wykorzystanie). Dane obejmujące Web of Science nie zostały załączone z powodu ograniczeń licencyjnych 
znajdujemy wpisy (do 45\%) na temat wszystkich artykułów zamieszczonych w PLOS, opublikowanych od lipca 2012 roku. Altmetryka to zróżnicowana grupa metryk, która okazuje się bardzo użyteczna, gdy naszym celem jest podzielenie metryk na podgrupy reprezentujące odpowiednie usługi, tj. serwisy zarządzania bibliografią i wymiany ocen i komentarzy (Mendeley, CiteULike), serwisy społecznościowe (Twitter, Facebook) czy blogi naukowe i media (ScienceSeeker, Research Blogging, Wikipedia).

Ogólnie rzecz biorąc, można powiedzieć, że dane dostarczone przez metryki mówią więcej niż suma ich indywidualnych składników. Od kwietnia 2013 roku odnotowano 158000000 odsłon stron z artykułami zamieszczonymi w PLOS, przy czym dokonano 32000000 pobrań (rys. 3). Zaledwie 460 000, czyli 0,3\% odsłon w HTML doprowadziło w rezultacie do cytowania, co uzmysławia, że samo skoncentrowanie się na cytowaniach artykułu nie uwzględniłoby ponad 99\% dowodów aktywności użytkowników związanej z danym artykułem.

Każda z metryk ma swój udział w ogólnej ocenie stanu badań. Oferują one jednocześnie różne i cząstkowe podsumowania. Innymi słowy, żaden z pojedynczych wskaźników w odosobnieniu nie może właściwie reprezentować rzeczywistego wpływu artykułu naukowego, choć liczba odsłon stron $\mathrm{z}$ artykułem niewątpliwie odzwierciedla zainteresowanie daną pracą i jest mocnym wskaźnikiem.

Rysunek 3. Article-level metrics dla 77385 artykułów z PLOS opublikowanych do 11 kwietnia 2013 roku. Odsłony stron HTML (HTML pageviews) oraz pobrania $\mathrm{w}$ formacie PDF (PDF downloads) ze strony prezentującej czasopisma dostępne w PLOS

thersase ners, pospiest

Serwisy z funkcjami społecznościowymi ułatwiające zarządzanie i dzielenie się publikacjami naukowymi, w szczególności te, które zorientowane są na wymianę naukowa, takie jak Mendeley czy CiteuLike, dostarczają ciekawych danych na temat materiałów zbieranych przez badaczy do swoich osobistych bibliotek na komputerach - $\mathrm{i}$ jest to bez wątpienia mocny wskaźnik dotyczący odniesień i zainteresowania. W połączeniu z tymi 
miarami szersza aktywność w mediach społecznościowych może okazać się bardzo bogata w informacje. Na przykład dzięki Twitterowi można prześledzić komunikację i interakcję osób w związku z konkretnymi artykułami, jednocześnie poznając powody takiej interakcji. Każda z metryk daje wgląd w zapis rozmów i komentarzy dotyczących badań, choć każda na swój sposób. W dodatku w sytuacji, w której wszystkie ALM-y oparte są na usługach sieciowych, istnieje możliwość walidacji krzyżowej (kroswalidacji) różnych typów metryk. Dzięki temu uzyskuje się cenny mechanizm gwarantujący zachowanie równowagi w ocenie.

\section{Studium przypadku}

Aby lepiej unaocznić bogactwo metryk na poziomie pojedynczego artykułu, przeanalizowaliśmy próbkę testową tworzącą zbiór dobrany z wszystkich artykułów PLOS opublikowanych przez autorów z tej samej instytucji (Hannover Medical School - instytucja, z którą afiliowany jest pierwszy z wymienionych autorów niniejszego artykułu). Przez wyszukiwanie pełnotekstowe odnaleziono 189 pozycji spełniających powyższe kryteria. Data dostępu: kwiecień 2011, wyszukiwań dokonano za pomocą wyszukiwarki umieszczonej w interfejsie PLOS Search $\mathrm{API}^{4}$. Zbiór danych i plik tekstowy $R$ script służący do zebrania danych są do wglądu i pobrania ${ }^{5}$. Wyszukiwanie pełnotekstowe przez afiliację mogło pominąć pojedyncze artykuły ze względu na fakt, że dane z nazwiskami autorów i ich organizacyjna przynależność nie zawsze są spójne i podawane konsekwentnie w tym samym zapisie (dotyczy to $\mathrm{np}$. nazwy organizacji podawanej $\mathrm{w}$ różnej postaci: „Hannover Medical School” lub „Medizinische Hochschule Hannover").

Podobnie jak w przypadku prawie wszystkich artykułów PLOS, otrzymany $w$ ten sposób zestaw artykułów wykazuje bardzo silną korelację (wynoszącą 4:1) pomiędzy liczbą odwiedzonych stron HTML a liczbą pobrań plików PDF (rysunek 4). Korelacja ta jest niezależna od wieku artykułu (niepokazane na rysunkach) ani od tytułu czasopisma. Dwa na trzy z najczęściej oglądanych artykułów są jednocześnie artykułami najczęściej cytowanymi w tym zestawie, choć ogólnie odnotowano jedynie słabą korelację pomiędzy wykorzystaniem (użyciem) a cytowaniem, co

4 M. Fenner, Example visualizations using the PLOS Search and ALM APIs, 2012, http://api.plos.org/2012/07/20/example-visualizations-using-the-plos-search-andalm-apis/\#more-1661 [dostęp: 11.04.2013].

5 M. Fenner, J. Lin, Article-Level Metrics Hannover Medical School, 2013, http://figshare.com/articles/Article_Level_Metrics_Hannover_Medical_School/681737 [dostęp: 4.10.2013]. 
jest zresztą spójne z danymi dotyczącymi pozostałych artykułów udostępnianych przez PLOS.

Ciekawym indywidualnym przypadkiem odbiegającym od tej reguły jest artykuł, którego stosunek pobrań do odsłon (PDF/HTML) wynosił $0,53^{6}$ (na rysunku 4 oznaczony pomarańczowym kołem - prawie 1500 pobrań plików PDF). Aby lepiej zrozumieć ten wzorzec, przyjrzeliśmy się odsłonom stron HTML i pobraniom plików PDF w dłuższym wymiarze czasowym (rysunek 5). Taki tymczasowy wzór wykorzystania typowy jest dla większości artykułów z czasopism, z przewagą pobrań w pierwszych miesiącach po opublikowaniu.

W tym właśnie okresie odsłonie strony z artykułem niemal zawsze towarzyszy pobranie pliku PDF, co skutkuje niezwykle wysokim wskaźnikiem proporcji PDF/HTML. Po upływie pięciu miesięcy od publikacji wskaźnik PDF/HTML wyraźnie obniża się i osiąga zdecydowanie niższe wartości.

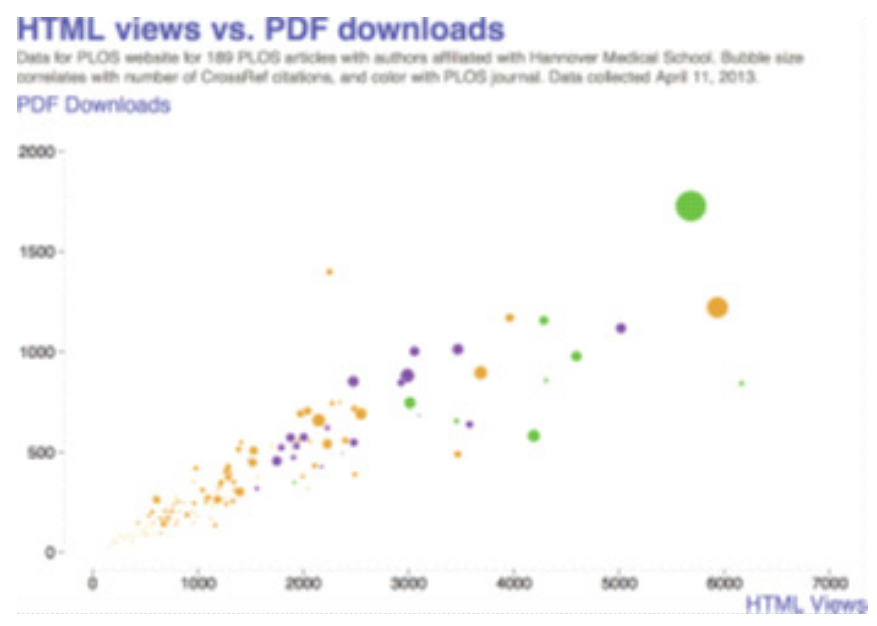

Rysunek 4. Odsłony stron w HTML a liczba pobrań plików PDF. Wyniki dla 189 artykułów dostępnych w PLOS, opublikowanych przez autorów zatrudnionych w Hannover Medical School. Kolory odpowiadają tytułom czasopism i zestawom zamieszczanym w PLOS (PLOS ONE - kolor zielony, PLOS Medicine, PLOS Pathogens, PLOS Neglected Tropical Diseases - kolor fioletowy, PLOS Biology, PLOS Genetics, PLOS Computational Biology - kolor zielony)

6 H. Walter, A. von Kalckreuth, D. Schardt, A. Stephan, T. Goschke, S. Erk, The temporal dynamics of voluntary emotion regulation, „PLOS ONE” 2009, t. 4 (8), e6726, http:// www. plosone.org/article/info\%3Adoi\%2F10.1371\%2Fjournal.pone.0006726 [dostęp: 11.05.2013]. 
Wielu badaczy wykorzystuje $\mathrm{w}$ celu uporządkowania i organizacji plików PDF z artykułami naukowymi pobranymi z sieci i przechowywanymi na swoich komputerach oprogramowania służące zarządzaniu i dzieleniu się publikacjami naukowymi. Jednym z bardziej popularnych programów do zarządzania bibliografią jest Mendeley, który udostępnia m.in. informację na temat liczby użytkowników, którzy dodali artykuł do swoich zakładek. W naszej próbce obejmującej 189 artykułów dostrzegamy wyraźną korelację pomiędzy liczbą pobrań plików PDF a liczbą zakładek wprowadzonych w programie Mendeley (rys. 6). Jest jednak niewielka grupa indywidualnych przypadków odstających od tego wzorca, np. artykuł, który najczęściej był zaznaczany w zakładkach [6], miał tylko przeciętną liczbę pobrań plików PDF.

Przedstawione studium przypadku zaledwie $\mathrm{w}$ niewielkim stopniu mogło pokazać potencjał zawarty w analizie metryk na poziomie artykułu, ale w oczywisty sposób dowodzi bezsprzecznej wartości gromadzenia metryk ALM czy komplementarności metryk innych niż cytowania, a także uzmysławia nam wartość śledzenia metryk, które należy odczytywać nie jako pojedyncze zbiory liczb, lecz we wzajemnym kontekście i na przestrzeni czasowej.

HTML Views
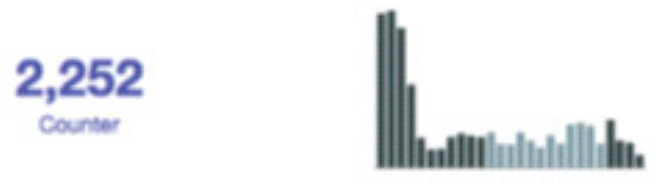

PDF Downloads
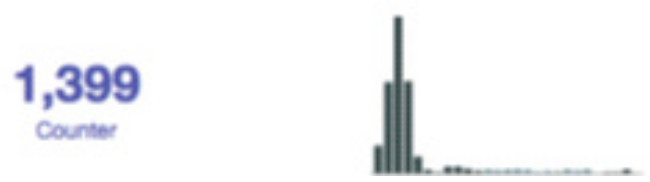

Rysunek 5. Miesięczne odsłony stron HTML (HTML views) i pobrania plików PDF (PDF downloads) ze strony internetowej PLOS $^{7}$ (data dostępu: 15 kwietnia 2013 roku)

7 F. Jessen, B. Wiese, H. Bickel, S. Eiffländer-Gorfer, A. Fuchs, H. Kaduszkiewics et al., Prediction of dementia in primary care patients, „PLOSONE” 2011, t. 6 (2), e16852, http:// www. plosone.org/article/info\%3Adoi\%2F10.1371\%2Fjournal.pone.0016852 [dostęp: 11.05.2013]. 


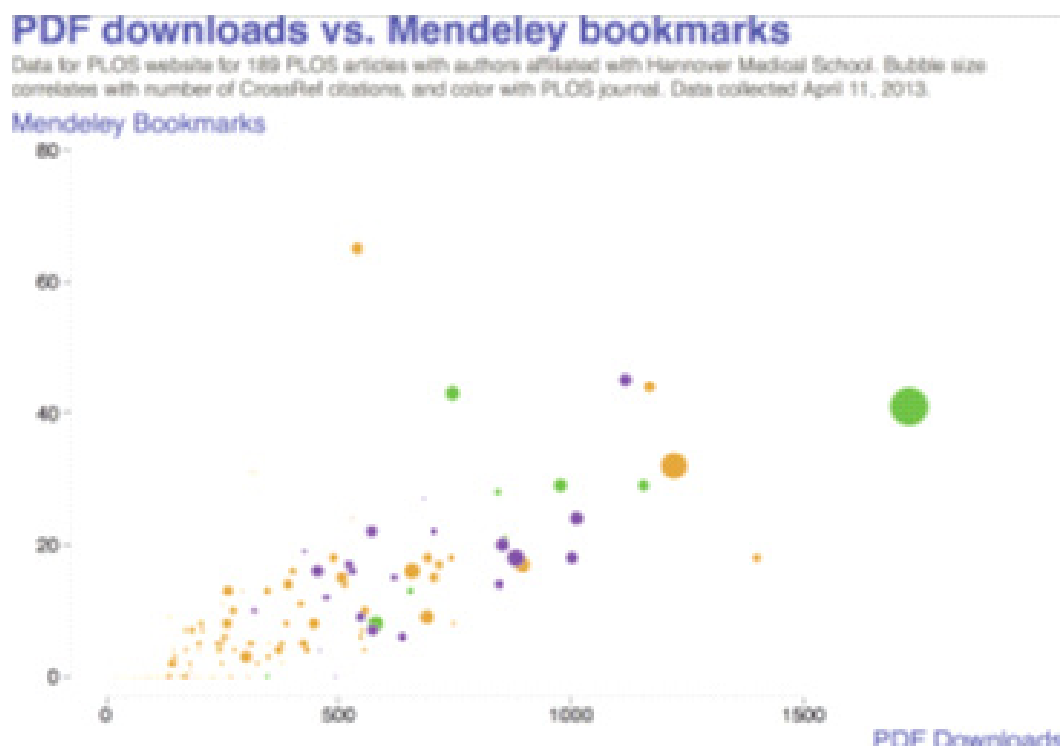

Rysunek 6. Pobrania plików PDF (PDF downloads) a liczba zakładek w serwisie zarządzania bibliografią Mendeley (Mendeley bookmarks) dla 189 artykułów dostępnych w PLOS i opublikowanych przez autorów z Hannover Medical School. Kolory odpowiadają tytułom czasopism i zestawów czasopism dostępnych w PLOS (PLOS ONE - kolor zielony, PLOS Medicine, PLOS Pathogens, PLOS Neglected Tropical Diseases - kolor fioletowy, PLOS Biology, PLOS Genetics, PLOS Computational Biology - kolor zielony)

\section{Wnioski}

Metryki na poziomie artykułu stwarzają oczywiście nowe możliwości w wykorzystaniu nowatorskich metod służących ocenie naukowego wskaźnika wpływu. Jak do tej pory, ich wartość polega przede wszystkim na umożliwieniu nawigacji, szybkiego poruszania się po ogromnych zasobach dostępnych treści czy monitorowania stanu badań. Nie ma wątpliwości, że stworzono niezwykle dynamiczny mechanizm i pole działania, które zdobywają coraz większą popularność i ulegają dalszej standaryzacji. Można założyć, że już w najbliższym czasie metryki ALM w sposób rutynowy będą stanowiły dodatkowe wsparcie w dokonywaniu ocen materiałów badawczych i naukowych. Jednocześnie ALM tworzą doskonały zestaw narzędzi, który może zostać wykorzystany do badań nad samym procesem komunikacji naukowej. Dzięki temu możemy dowiedzieć się wiele o tym, w jaki sposób wyniki badań naukowych 
są rozpowszechniane i dyskutowane i jak są ponownie wykorzystywane już po ich publikacji.

Przeł. Tomasz Olszewski

\author{
MARTIN FENNER, JENNIFER LIN
}

\title{
Novel Research Impact Indicators
}

\begin{abstract}
Citation counts and more recently usage statistics provide valuable information about the attention and research impact associated with scholarly publications. The open access publisher Public Library of Science (PLOS), a nonprofit publisher and advocacy organization founded to accelerate progress in science and medicine by leading a transformation in research communication, has pioneered the concept of article-level metrics, where these metrics are collected on a per article and not a per journal basis and are complemented by real-time data from the social web or altmetrics: blog posts, social bookmarks, social media and other.
\end{abstract}

Key words: article-level metrics, altmetrics, research impact. 